
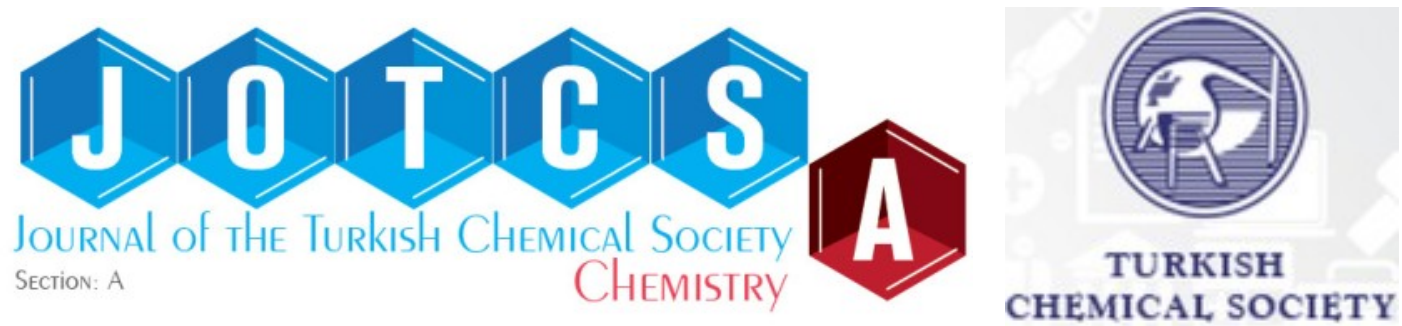

\title{
Source Analysis of Heavy Metals and Polycyclic Aromatic Hydrocarbons from a Popular Dumpsite, Lagos State, Nigeria
}

\author{
Aminat Aderonke MOHAMMED ${ }^{1} \otimes$ iD, Paschal Okiroro INIAGHE $\square$, \\ Taofeeqat Omotayo ABU ${ }^{1} \triangle D$, Mojeed Olalekan BELLO ${ }^{3}$ \\ and Mariam Damilola ABDULKADIR ${ }^{1}$ iD
}

1Department of Industrial Chemistry, Faculty of Physical Science, University of Ilorin, Ilorin, Nigeria. 2Department of Chemistry, Faculty of Science, Federal University Otuoke, Nigeria. 3Department of Chemistry, Faculty of Science, University of Ilorin, Ilorin, Nigeria.

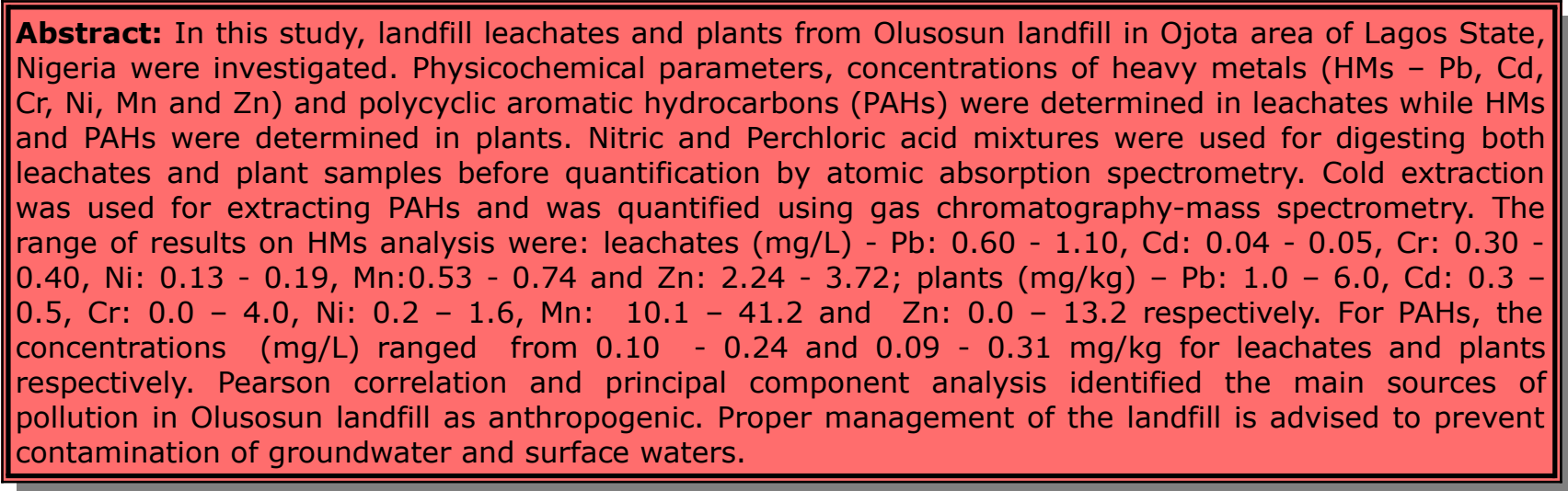

Keywords: Landfill leachate, heavy metals, Olusosun, polycyclic aromatic hydrocarbons, plants.

Submitted: February 10, 2020. Accepted: May 15, 2020.

Cite this: MOHAMMED AA, INIAGHE PO, ABU TO, BELLO MO, ABDULKADIR MD. Source Analysis of Heavy Metals and Polycyclic Aromatic Hydrocarbons from a Popular Dumpsite, Lagos State, Nigeria. JOTCSA. $2020 ; 7(2): 489-504$.

DOI: https://doi.org/10.18596/jotcsa.687322.

*Corresponding author. E-mail: mohammed.aa@unilorin.edu.ng.

\section{INTRODUCTION}

Rapid urbanization and increasing population growth increase waste generation (1). Management of solid waste is an environmental challenge in many urbanized areas of the world (2). Landfilling is a standard method of waste disposal in several developing countries (3). However, the quality of many landfill sites is far from recommended standards mainly because the landfill systems are not correctly engineered and suited with the requisite leachate collection facilities and installation. These landfills thus serve as repositories for many toxic substances $(4,5)$. The extent of the threats posed by these landfills depends on the depth of the water table, the direction of the groundwater flow, permeability of the geologic strata, the concentration and level of pollutants in the leachates, and municipal solid waste type (6).

Leachates are mixtures of dissolved inorganic and organic compounds as well as microbes generated via the percolation of water through disposed of 
solid wastes in a landfill (5). Several factors are responsible for leachates composition, including the kind of waste deposited on the landfill, degree of compaction, particle size, the composition of the wastes, the age of the landfill, the climate, hydrology of the site and other various peculiar conditions such as landfill design and type of liner used (7). Leachates can thus contain substantial amounts of organic (polycyclic aromatic hydrocarbons (PAHs), persistent organic pollutants (POPs), polychlorinated biphenyls (PCBs)) and inorganic (heavy metals) pollutants $(8,9)$. They can also serve as indicators of environmental pollution through their ability to leak, percolate, and contaminate groundwater (10).

There has been a growing interest regarding the possible harmful effects of PAHs released into the environment from anthropogenic sources as several PAHs have been reported to exhibit mutagenic and carcinogenic properties $(3,11)$. Furthermore, uncontrolled inputs of heavy metals into the environment are unpleasant and undesirable due to non-biodegradability and bioaccumulation in soil, underground water, or plants; and the toxicity of several heavy metals is well documented in the literature. Leachate production via decayed solid waste materials mixed with precipitates of surface waters can bring about contamination of plants, surface and sub-surface water collection systems, and transportation of the contamination to the farther point of the ecosystem (12) while the volume of leachate generated in a landfill depends on the amount of solid waste deposited, water availability, condition of the landfill, and deposited refuse, as well as the soil condition (3). Leachate outflow and infiltration are reported to be the primary source of groundwater contamination from existing landfills (13).

In Lagos metropolis, three dumpsites - Olusosun, Solus, and Abule-Egba - are in use, with Olusosun being the most active in terms of quantity of waste generated daily (14). There are several reports on the state of different landfill sites in Lagos with particular interest on contamination of leachates and surrounding soils by heavy metals $(10,15,16)$ and PAHs (17). However, the impact of heavy metals and PAHs from leachates on plants growing on the dumpsite is lacking. Therefore, in this study, the physicochemical properties, level of heavy metals and polycyclic aromatic hydrocarbons in leachates and plants from Olusosun dumpsite, were investigated

\section{MATERIAL AND METHODS}

\section{Description of study area}

Olusosun landfill is located in the Ojota area of Lagos State, Nigeria (Figure 1). It is known to be the largest landfill in Lagos State and ranked among the biggest in the world. It has been in existence since 1978 (18), occupies 42 hectares of land, and receives approximately $40 \%$ of the total waste deposit Lagosians (19). It lies between latitude $6^{\circ}$. $20^{\prime} \mathrm{N}$ and longitude $3^{\circ}$. 20' $\mathrm{E}$. Various human activities take place around this vicinity, including automobile repairs, petrol fueling stations (18), and motor parks. The landfill does not have any protective bottom layer constructed to protect leachate plumes from migrating into groundwater.

\section{Sample collection}

Five Leachate samples were collected from each of the three leachate streams flowing out of the base of the landfill to make a composite (L1). Another five leachate samples (L2) were collected from the main pond located within the vicinity of the landfill. Each of the composite samples was placed in $1 \mathrm{~L}$ pre-cleaned plastic bottles with the cap securely tightened, preserved in ice-chest, taken to the laboratory, and stored in a refrigerator at 4 oC pending analysis. Sample bottles were rinsed with the leachates before sample collection. 


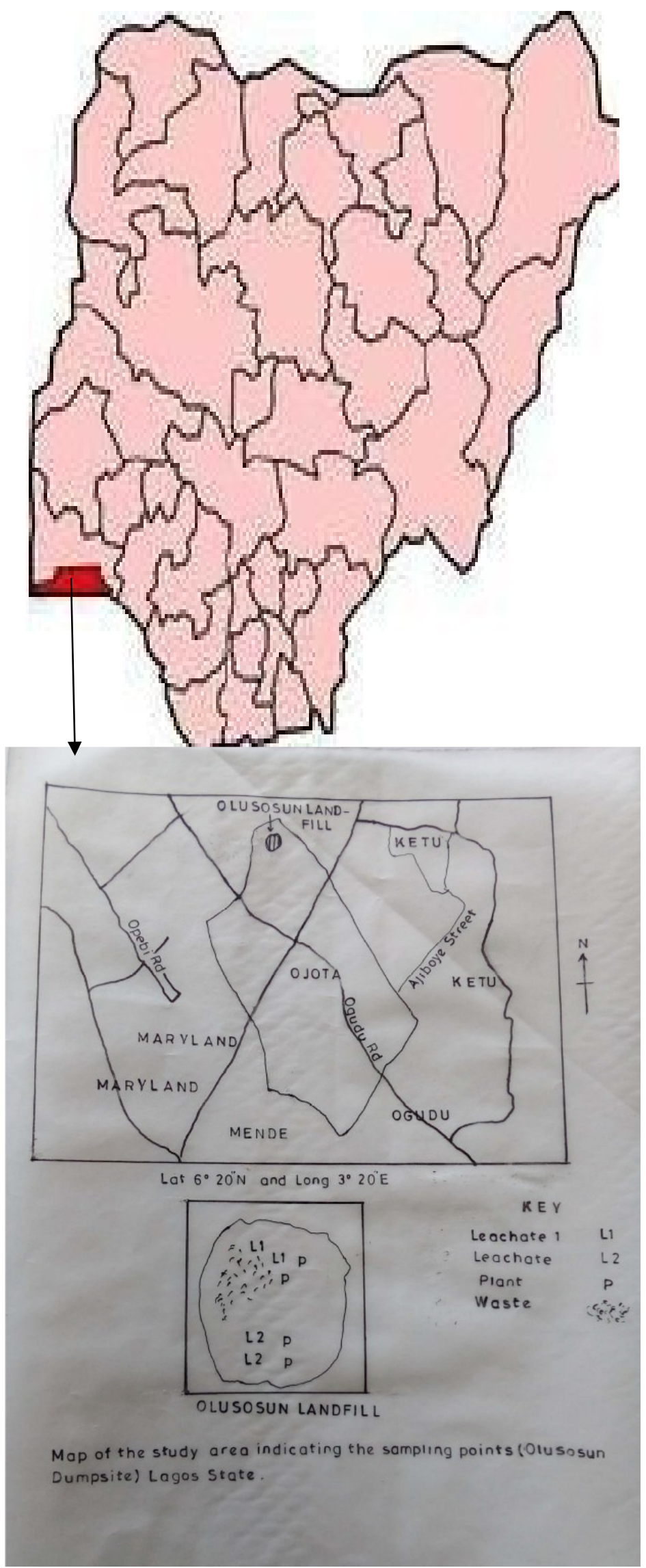

Figure 1: Map of the Study Area. (the red portion in the south-west quadrant). 
The leaves of three different plants - pawpaw (Carica papaya, $\mathrm{P}_{1}$ ), pepper (Capsicum annum, $\mathrm{P}_{2}$ ) and banana (Musa acuminata, $\mathrm{P}_{3}$ ) - were collected within the vicinity of L1 and L2. The collected plant leaves were placed in pre-cleaned polyethylene bags and transported to the laboratory. The plants were identified at the Department of Plant Biology, University of Ilorin, Nigeria. In the laboratory, the leaves were rinsed with tap water and distilled water and air-dried at room temperature. The dried samples were ground using an agate mortar and pestle and sieved using a $2 \mathrm{~mm}$ mesh size sieve.

\section{Physico-chemical parameters}

The $\mathrm{pH}$ of composite leachate samples was measured in-situ using a portable digital $\mathrm{pH}$ meter ( $\mathrm{pHep} \otimes$ Hanna, USA), which had been previously calibrated with buffer solutions of $\mathrm{pH} 4$ and 7 , respectively. The temperature was also determined in-situ using a thermometer. Electrical conductivity (EC) was measured with a conductivity meter calibrated with a potassium chloride solution. Colour was determined using colorimetry. Total dissolved solids (TDS) was determined gravimetrically by evaporating a known volume of leachate to dryness in a pre-weighed crucible on a steam bath. Total suspended solids (TSS) were also determined gravimetrically by evaporating a known volume of filtered leachate to dryness in a pre-weighed crucible on a steam bath. Biochemical oxygen demand (BOD), chemical oxygen demand (COD), chloride $(\mathrm{Cl}-)$, and hardness were determined titrimetrically. The concentration of sulfate $\left(\mathrm{SO}_{4}{ }^{2-}\right)$ was determined turbidimetrically, phosphate $\left(\mathrm{PO}_{4}{ }^{3-}\right)$ was determined via the colorimetric method, and nitrate $\left(\mathrm{NO}_{3}{ }^{-}\right)$was determined using the brucine method (20).

\section{Analysis of heavy metals in leachates and plant samples}

$50 \mathrm{~mL}$ of each leachate samples were treated with $10 \mathrm{~mL}$ of concentrated $\mathrm{HNO}_{3}$ and $5 \mathrm{~mL}$ of $\mathrm{HClO}_{4}$. The entire mixture was heated in a digestion block at $125^{\circ} \mathrm{C}$ until white fumes are observed to confirm the complete utilization of the acid, and the volume was reduced to about $25 \mathrm{~mL}$. The mixture was removed from the block, cooled, filtered using a Whatman No. 40 filter paper, transferred to a $50 \mathrm{~mL}$ volumetric flask and made up to mark with distilled water (21). Atomic absorption spectrophotometer (Buck Scientific Model 210 VGP, USA) was then used for quantification of the following metals: $\mathrm{Pb}, \mathrm{Cd}, \mathrm{Cr}$, $\mathrm{Ni}, \mathrm{Mn}$, and $\mathrm{Zn}$. All samples were prepared in duplicate.

For plant samples, approximately $5.00 \mathrm{~g}$ of each of the powdered leaf samples was placed in a $25 \mathrm{~mL}$ conical flask. $10 \mathrm{~mL}$ of concentrated $\mathrm{HNO}_{3}$ was added, followed by $5 \mathrm{~mL}$ of $\mathrm{HClO}_{4}$. The contents of the flask were heated at $150{ }^{\circ} \mathrm{C}$ for 1 hour in a fuming hood and then cooled to room temperature. After that, $20 \mathrm{~mL}$ of distilled water was added, and the mixture was filtered using filter paper in a 50 $\mathrm{mL}$ volumetric flask (21). Atomic absorption spectrophotometer was also used for quantification of the following metals: $\mathrm{Pb}, \mathrm{Cd}, \mathrm{Cr}, \mathrm{Ni}, \mathrm{Mn}$ and $\mathrm{Zn}$. All samples were prepared in duplicate.

\section{Analysis of PAHs in leachate and plant leaves}

For extraction and clean-up of PAHs in leachates, $100 \mathrm{~mL}$ of thoroughly mixed leachate sample was filtered using clean cotton wool to attain a clear solution without particles into a separating funnel. A $100 \mathrm{~mL}$ mixture of $\mathrm{n}$-hexane and dichloromethane $1: 1(\mathrm{v} / \mathrm{v})$ was added, and the separating funnel was left undisturbed on a retort stand for about 30 minutes. The separating funnel was then opened to drain the water phase while the organic phase was collected in a glass funnel containing $20 \mathrm{~g}$ of anhydrous sodium sulfate plugged with a ball of cotton wool. A second extraction was carried out on the organic phase and was re-extracted using a 50 $\mathrm{mL}$ mixture of dichloromethane and $\mathrm{n}$-hexane $1: 1$ $(\mathrm{v} / \mathrm{v})$. The extract was concentrated to an absolute $20 \mathrm{~mL}$ prior to the determination of PAHs $(22,23)$.

For plant leaves, a $2.00 \mathrm{~g}$ of each ground plant sample was weighed into a clean extraction container. $10 \mathrm{~mL}$ of dichloromethane was added and left for 20 minutes. Another $20 \mathrm{~mL}$ of dichloromethane was added again to the mixture and was then filtered into an extraction bottle. The extracted sample was concentrated to $3 \mathrm{~mL}$ for separation. The column was packed with $1 \mathrm{~g}$ of moderately packed cotton wool. $3 \mathrm{~g}$ of dried activated silica gel was then poured into the column, and $0.6 \mathrm{~mL}$ of sodium sulfate was added. The column was rinsed with $20 \mathrm{~mL}$ of dichloromethane to allow it to run through the silica gel. Pre-elution with dichloromethane $(20 \mathrm{~mL})$ was allowed to flow through the column for about 2 minutes, and $3 \mathrm{~mL}$ of the plant sample was poured immediately into the column. The stop-cork of the chromatographic column was opened, and the eluent was collected at intervals with a $10 \mathrm{~mL}$ graduated cylinder. Due to exposure of sodium sulfate to air, dichloromethane was added at intervals to the column in increments of $5 \mathrm{~mL}$. The concentrated fractions were then transferred in a glass bottle with rubber crimps caps for GC-MS analysis (24). All samples were prepared in duplicate.

Extracts from leachates and plant leaves were analyzed for 16 PAHs by gas chromatography-mass spectrometry (GC-MS, Agilent 7890B GCMS, USA).

\section{Data Analysis}

All the experimental data were subjected to further statistical analyses such as Analysis of variance (ANOVA), Pearson correlation matrix, and principal component analysis to determine the source of pollution from the studied landfill (Olusosun) using Origin pro 2018. 


\section{RESULTS AND DISCUSSION}

\section{Physico-chemical properties of leachate}

Physico-chemical properties of leachates obtained from Olusosun dumpsite are presented in Table 1. The $\mathrm{pH}$ values, ranging from 7.3 - 7.5, indicates slight alkalinity of the leachates. Leachate $\mathrm{pH}$ values are reported to increase with age and are usually greater than $7(10,17,25)$. Values of $\mathrm{pH}$ greater than 7 may be attributed to high salinity, an increase in the utilization of unionized free volatile fatty acids by bacteria, and a decrease in shortchain fatty acids (26). The $\mathrm{pH}$ also serves as an indicator of the chemical state in which an environmental species will be present, and $\mathrm{pH}$ dependent species such as heavy metals may become environmentally available at low $\mathrm{pH}$ (27). Hence, the metals' bioavailability might be low. Similarly, alkaline values have been reported for landfill leachates $(10,16,17,26)$. The TDS values ranged from $5880-6500 \mathrm{mg} / \mathrm{L}$. High TDS values imply the presence of a large concentration of soluble ions, leaching of the ions, and dissolved organic matter from the landfill caused by the hydrogeological, physical, and chemical conditions from the landfill, including chlorides, carbonates, phosphates, nitrates among others (27). The range of concentration values for TSS, BOD, COD, NO -, $\mathrm{PO}_{4}{ }^{3-}, \mathrm{Cl}^{-}, \mathrm{TH}$ and $\mathrm{SO}_{4}{ }^{2-}$ are: $1260-1805 \mathrm{mg} / \mathrm{L}, 640-$
$658.2 \mathrm{mg} / \mathrm{L}, 2788-2866 \mathrm{mg} / \mathrm{L}, 18.4-21.2 \mathrm{mg} / \mathrm{L}, 9.0-$ $9.8 \mathrm{mg} / \mathrm{L}, 3439-3471 \mathrm{mg} / \mathrm{L}, 7305-7670 \mathrm{mg} / \mathrm{L}$ and 107-150 mg/L, respectively. All but $\mathrm{SO}_{4}{ }^{2-}$ exceeded their respective limits set by WHO (29) and NESREA (30). A high BOD level implies that the leachate cannot undergo self-purification, and therefore require some form of pre-treatment. Similarly, a $\mathrm{BOD} / \mathrm{COD}$ ratio greater than 0.2 indicates that the leachate is old and relatively stable (17). For $\mathrm{Cl}-$, no harmful level is reported in humans, but high concentrations exceeding the $250 \mathrm{mg} / \mathrm{L}$ permissible limit may be harmful to and cause damage to plants. The concentration of sulfate at high amounts in landfill leachate is reported to depend on depends on the following factors: landfill age, composition of waste, the biological, physical, and chemical composition (31). Nitrate level concentration values are important factors in determining the extent of pollution in leachates. Phosphate at high concentrations can lead to oxygen depletion of water bodies via eutrophication with a response to an increasing level of nutrients due to the presence of phosphates and nitrates (32). The color of the leachates was found to be very black, which is a result of the changes in the oxidation state of $\mathrm{Fe}^{2+}$ (ferrous ions) to $\mathrm{Fe}^{3+}$ (ferric ions). The ferric ion forms ferric hydroxide colloids and fulvic complexes contributing to the blackish color of the leachates (26).

Table 1: Physico-chemical properties of leachates

\begin{tabular}{|c|c|c|c|c|}
\hline & \multicolumn{4}{|c|}{ Leachates } \\
\hline Parameters & $\mathbf{L}_{\mathbf{1}}$ & $\mathbf{L}_{2}$ & $*$ & $* *$ \\
\hline Color & Black & Black & Colorless & - \\
\hline$\overline{\mathrm{pH}}$ & $7.5 \pm 0.10$ & $7.3 \pm 0.10$ & $6.0-9.0$ & $6.5-9.5$ \\
\hline $\mathrm{EC}(\mu \mathrm{S} / \mathrm{cm})$ & $724.0 \pm 0.40$ & $740.0 \pm 0.90$ & & 1000.0 \\
\hline TDS (mg/L) & $6500.0 \pm 0.90$ & $6880.0 \pm 1.30$ & $\overline{5} 00.0$ & 500.0 \\
\hline Temperature $\left({ }^{\circ} \mathrm{C}\right)$ & $17.0 \pm 0.90$ & $18.7 \pm 0.10$ & 40.0 & - \\
\hline BOD (mg/L) & $640.0 \pm 0.51$ & $658.2 \pm 0.90$ & 50.0 & - \\
\hline COD $(\mathrm{mg} / \mathrm{L})$ & $2788.0 \pm 0.20$ & $2868.0 \pm 1.10$ & 90.0 & \\
\hline $\mathrm{Cl}^{-}(\mathrm{mg} / \mathrm{L})$ & $3439.0 \pm 0.80$ & $3471.0 \pm 1.11$ & 250.0 & 250.0 \\
\hline $\mathrm{TH}(\mathrm{mg} / \mathrm{L})$ & $7305.0 \pm 0.90$ & $7670.0 \pm 0.71$ & - & 180.0 \\
\hline TSS (mg/L) & $1260.0 \pm 1.10$ & $1505.0 \pm 0.92$ & 25.0 & _ \\
\hline $\mathrm{SO}_{4}{ }^{2-}(\mathrm{mg} / \mathrm{L})$ & $107.0 \pm 0.30$ & $150.0 \pm 0.90$ & 250.0 & 250.0 \\
\hline $\mathrm{NO}_{3}{ }^{-}(\mathrm{mg} / \mathrm{L})$ & $18.4 \pm 0.01$ & $21.2 \pm 0.20$ & 10.0 & 50.0 \\
\hline $\begin{array}{l}\mathrm{PO}_{4}{ }^{3-}(\mathrm{mg} / \mathrm{L}) \\
{ }^{*}{ }^{2} E S R E A, 2011\end{array}$ & $8.0 \pm 0.50$ & $9.8 \pm 0.03$ & 2.0 .0 & - \\
\hline **WHO, 2007 & & & & \\
\hline
\end{tabular}


Table 2: Pearson correlation matrix of the physicochemical parameters of leachate from Olusosun Landfill

\begin{tabular}{|c|c|c|c|c|c|c|c|c|c|c|c|c|}
\hline & pH & EC & TDS & Temp. & BOD & COD & $\mathrm{Cl}^{-}$ & TH & TSS & $\mathrm{SO}_{4}{ }^{2-}$ & $\mathrm{NO}_{3}^{-}$ & $\mathrm{PO}_{4}{ }^{3-}$ \\
\hline$\overline{\mathrm{pH}}$ & 1 & & & & & & & & & & & \\
\hline EC & -0.4096 & 1 & & & & & & & & & & \\
\hline TDS & -0.8504 & 0.8283 & 1 & & & & & & & & & \\
\hline Temp. & -0.5903 & 0.9782 & 0.9267 & 1 & & & & & & & & \\
\hline BOD & -0.8361 & 0.8429 & 0.9996 & 0.9363 & 1 & & & & & & & \\
\hline COD & -0.7219 & 0.9270 & 0.9780 & 0.9847 & 0.9832 & 1 & & & & & & \\
\hline $\mathrm{Cl}-$ & -0.8072 & 0.8692 & 0.9970 & 0.9530 & 0.9987 & 0.9912 & 1 & & & & & \\
\hline $\mathrm{TH}$ & -0.7665 & 0.8999 & 0.9897 & 0.9709 & 0.9932 & 0.9978 & 0.9978 & 1 & & & & \\
\hline TSS & -0.8085 & 0.8681 & 0.9972 & 0.9523 & 0.9988 & 0.9909 & 0.9965 & 0.9977 & 1 & & & \\
\hline $\mathrm{SO}_{4}^{2-}$ & -0.7672 & 0.8994 & 0.9899 & 0.9706 & 0.9933 & 0.9977 & 0.9979 & 0.9968 & 0.9978 & 1 & & \\
\hline $\mathrm{NO}_{3}^{-}$ & -0.9209 & 0.7329 & 0.9883 & 0.8583 & 0.9838 & 0.9346 & 0.9735 & 0.9563 & 0.9740 & 0.9565 & 1 & \\
\hline $\mathrm{PO}_{4}{ }^{3-}$ & -0.9226 & 0.7298 & 0.9876 & 0.8560 & 0.9830 & 0.9330 & 0.9724 & 0.9549 & 0.9729 & 0.9552 & 0.9999 & 1 \\
\hline
\end{tabular}

Two-tailed significance is used. 
The physicochemical parameters for all the leachates were analyzed with Origin pro 2018 using one-way ANOVA (Analysis of variance), which showed that all the physicochemical parameters analyzed were significantly different ( $p>0.05$ level). Also, Pearson correlation was used to analyze the physicochemical parameters, as shown in Table 2 above. The $\mathrm{pH}$ showed a negative correlation with EC $(p=0.7313)$, TDS $(p=0.3527)$, Temp. $(p=$ $0.5980)$, BOD $(p=0.3697), \operatorname{COD}(p=0.4865), \mathrm{TH}$ $(p=0.4440)$, TSS $(p=0.4006), \mathrm{Cl}^{-}(p=0.4020)$, $\mathrm{SO}_{4}{ }^{2-} \quad(p=0.4434), \mathrm{NO}_{3}{ }^{-}(\mathrm{p}=0.2550), \mathrm{PO}_{4}{ }^{3-}$ $(0.2521)$. There was a positive correlation among other physicochemical parameters with which includes $\mathrm{EC}$ vs. TDS, $\mathrm{SO}_{4}{ }^{2-}$ vs. $\mathrm{NO}_{3}{ }^{-}, \mathrm{TH}$ vs. $\mathrm{PO}_{4}{ }^{3-}$ $\mathrm{BOD}$ vs. $\mathrm{Cl}^{-}, \mathrm{Temp}$. vs. $\mathrm{SO}_{4}{ }^{2-}, \mathrm{COD}$ vs. $\mathrm{TH}, \mathrm{Cl}^{-}$vs. TH, TDS vs. Temp., TDS vs. BOD, Temp. vs. COD, EC vs. Temp., $\mathrm{Cl}^{-}$vs. $\mathrm{SO}_{4}{ }^{2-}, \mathrm{BOD}$ vs. TSS, TDS vs. $\mathrm{PO}_{4}{ }^{3-}, \mathrm{COD}$ vs. $\mathrm{SO}_{4}{ }^{2-}$, TDS vs. TSS, BOD vs. COD, Temp. vs. TH, TSS vs. $\mathrm{NO}_{3}^{-}, \mathrm{BOD}$ vs. TH, EC vs. $\mathrm{NO}_{3}{ }^{-}, \mathrm{Cl}^{-}$vs. Temp., BOD vs. TSS, EC vs. TSS, TDS vs. $\mathrm{NO}_{3}{ }^{-} \mathrm{TH}$ vs. $\mathrm{SO}_{4}{ }^{2-}$, Temp. vs. $\mathrm{PO}_{4}{ }^{3-}, \mathrm{TH}$ vs. $\mathrm{NO}_{3}{ }^{-}$, TSS vs. $\mathrm{SO}_{4}{ }^{2-}, \mathrm{EC}$ vs. $\mathrm{BOD}$, and $\mathrm{NO}_{3}{ }^{-}$ vs. $\mathrm{PO}_{4}{ }^{3-}$. With the results from Pearson correlation, it can be deduced that the landfill is heavily polluted with diverse kinds of wastes dumped from the residents in this State.

\section{Heavy metal concentrations in leachates and plant leaves}

The concentrations of heavy metals $(\mathrm{mg} / \mathrm{L})$ in leachate samples were: $0.60-1.10$ for $\mathrm{Pb}, 0.04$ 0.05 for $\mathrm{Cd}, 0.30$ - 0.40 for $\mathrm{Cr}, 0.13-0.19$ for $\mathrm{Ni}$, 2.24 - 3.72 for $\mathrm{Zn}$ and 0.53 - 0.74 for $\mathrm{Mn}$, respectively as shown from Figure 2 below. The increasing order of metals concentration metals in the leachate samples followed the order: $\mathrm{Zn}>\mathrm{Pb}>\mathrm{Mn}>\mathrm{Cr}>\mathrm{Ni}>\mathrm{Cd}$. These values are similar to the results obtained elsewhere (17) but slightly higher than those reported elsewhere (28). All analyzed metals in leachates samples exceeded their respective permissible limits set by WHO (29) and NESREA (30) except Cd, which was lower than the NESREA (30) permissible limit. The presence of heavy metals in both leachates can be attributed to the type of waste being deposited on the landfill site, which in turn is a function of the industrialized nature of the study areas.

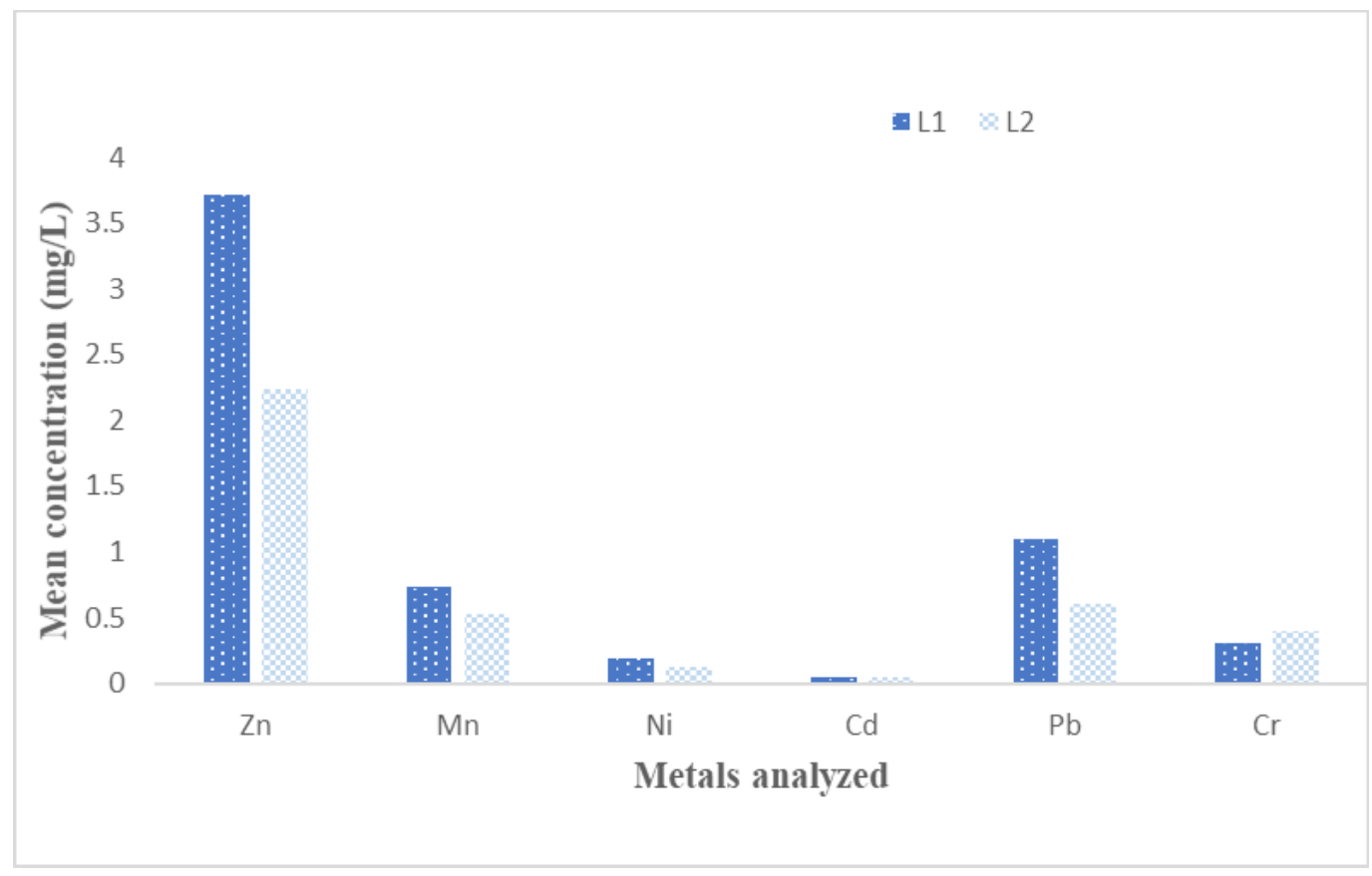

Figure 2: Metal concentrations in leachate samples.

The mean concentrations of heavy metals in plant samples analyzed are shown in Figure 3 below. The increasing order of metals concentration in plant samples followed the order: $\mathrm{Mn}>\mathrm{Zn}>\mathrm{Pb}>\mathrm{Cr}>\mathrm{Ni}>\mathrm{Cd}$.
The concentration of heavy metals in all plant samples were all below their respective permissible limits set by WHO (33) (50 mg/kg for $\mathrm{Zn}, 10 \mathrm{mg} / \mathrm{kg}$ for $\mathrm{Ni}, 0.02 \mathrm{mg} / \mathrm{kg}$ for $\mathrm{Cd}, 2 \mathrm{mg} / \mathrm{kg}$ for $\mathrm{Pb}$ and 1.3 $\mathrm{mg} / \mathrm{kg}$ for $\mathrm{Cr}$ ). 


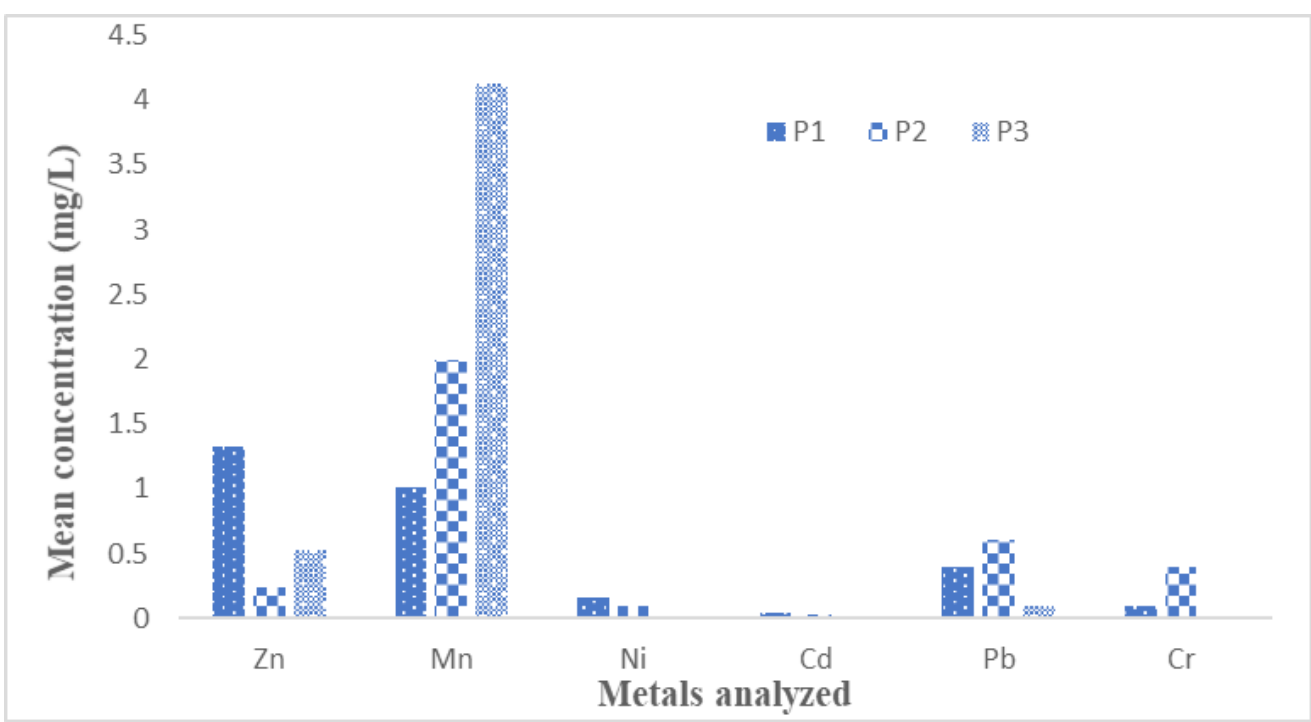

Figure 3: Metal concentrations in plant leaves.

Table 3: Pearson correlation matrix of heavy metals from leachates Samples in the Olusosun landfill.

\begin{tabular}{|c|c|c|c|c|c|c|}
\hline & $\mathrm{Zn}$ & $M n$ & $\mathrm{Ni}$ & $\mathrm{Cd}$ & $\mathrm{Pb}$ & $\mathrm{Cr}$ \\
\hline $\mathrm{Zn}$ & 1 & & & & & \\
\hline $\mathrm{Mn}$ & 0.9411 & 1 & & & & \\
\hline $\mathrm{Ni}$ & 0.7827 & 0.9471 & 1 & & & \\
\hline $\mathrm{Cd}$ & 0.7278 & 0.4530 & 0.1429 & 1 & & \\
\hline $\mathrm{Pb}$ & 0.8967 & 0.9936 & 0.9774 & 0.3491 & 1 & \\
\hline $\mathrm{Cr}$ & 0.1477 & -0.1956 & -0.5000 & 0.7857 & -0.3054 & 1 \\
\hline
\end{tabular}

Two tailed $(p>0.05$ level)

Table 4: Pearson correlation matrix of heavy metals from the plant samples in the Olusosun landfill.

\begin{tabular}{|c|c|c|c|c|c|c|}
\hline & Zn & Mn & $\mathbf{N i}$ & Cd & $\mathbf{P b}$ & $\mathbf{C r}$ \\
\hline $\mathrm{Zn}$ & 1 & & & & & \\
\hline $\mathrm{Mn}$ & -0.5434 & 1 & & & & \\
\hline $\mathrm{Ni}$ & 0.7067 & -0.9780 & 1 & & & \\
\hline $\mathrm{Cd}$ & 0.7067 & -0.9780 & 0.6215 & 1 & & \\
\hline $\mathrm{Pb}$ & -0.1469 & -0.7506 & 0.5960 & 0.5960 & 1 & \\
\hline $\mathrm{Cr}$ & -0.5171 & -0.4376 & 0.2402 & 0.2402 & 0.9226 & 1 \\
\hline
\end{tabular}

Two tailed $(p>0.05$ level)

From Table 3 above, there is a strong positive correlation between $\mathrm{Zn}$ with other metals such as $M n(p=0.2197), N i(p=0.4277), C d(p=0.4811)$, $\mathrm{Pb} \quad(p=0.2919)$ and $\mathrm{Cr} \quad(p=0.9057)$. Also, there is a positive correlation in $\mathrm{Mn}$ versus $\mathrm{Ni}$ ( $\mathrm{p}=$ $0.2080), M n$ versus $\mathrm{Pb}(\mathrm{p}=0.0723)), \mathrm{Ni}$ versus $\mathrm{Pb}$ $(p=0.1357)$, and $C d$ versus $\mathrm{Cr}(p=0.4246)$ and slight correlation between $\mathrm{Ni}$ versus $\mathrm{Cd}(\mathrm{p}=$ $0.9087), M n$ versus $C d(p=0.7007)$ and $C d$ versus $\mathrm{Pb} \quad(\mathrm{p}=0.7730)$. A negative correlation was identified between $\mathrm{Mn}$ versus $\mathrm{Cr}(\mathrm{p}=0.8747)$, $\mathrm{Ni}$ versus $\mathrm{Cr}(\mathrm{p}=0.6667)$ and $\mathrm{Pb}$ versus $\mathrm{Cr}(\mathrm{p}=$ 0.8024). The Pearson correlation of the plant samples is shown in Table 4 above. A negative correlation was identified between $\mathrm{Zn}$ vs. $\mathrm{Mn}$ ( $\mathrm{p}=$ $0.6343), Z n$ vs. $\mathrm{Cr}(p=0.6540), M n$ vs. $\mathrm{Ni}$ ( $p$ $=0.1339)$, Mn vs. $\mathrm{Pb}(p=0.4596), M n$ vs. $\mathrm{Cr}(p=0$. $0.7117)$ and slight correlation exist between $\mathrm{Ni}$ vs. $\mathrm{Pb}(\mathrm{p}=0.8456)$ and very strong correlation exist between $\mathrm{Zn}$ vs. $\mathrm{Ni}$ and $\mathrm{Zn}$ vs. Cd having the same values ( $p=0.5004)$, Ni vs. Cd, Cd vs. $\mathrm{Pb}$ are also having the same values $(p=0.5935)$. The correlation between the metals analyzed was from a similar source (34), and this confirmed that the landfill was contaminated with different composition of solid wastes dumped on this landfill, which percolated into soil and then contaminated the plants grown from this site. The relatively high concentrations recorded for $\mathrm{Mn}$ in plant leaves compared with leachate concentrations could be attributed to different degrees in bioaccumulation of $\mathrm{Mn}$ by the different plant laves studied.

The eigenvalues obtained from any data are used to determine components that are retained. A set of data having eigenvalues greater than unity indicates a component that is retrained, but when it is less than unity, the component is not retained $(35,36)$. The scree plot of heavy metals in leachates and plants were shown from Figure 4 below. There were 
five components from each scree plot of leachates and plants. Components 1 and 2 are retained with eigenvalues of 4.00 and 1.97 respectively for both leachates and plants, while other components (3-6) are not retrained. However, components 1 and 2 are retrained for leachates and plants because the eigenvalues are greater than unity, as shown in Figure 5. It is similar to the previous research from the assessment of heavy metals from roadside dust in Ilorin (36). The two principal components analysis (PC 1 and PC 2) from heavy metals in leachate samples has a variance of $66.99 \%$ and $33.01 \%$, respectively, as shown from Figure 6 below.

In the plant samples, the PC 1 and 2 have $66.05 \%$ and $33.95 \%$ variance, respectively, as shown from

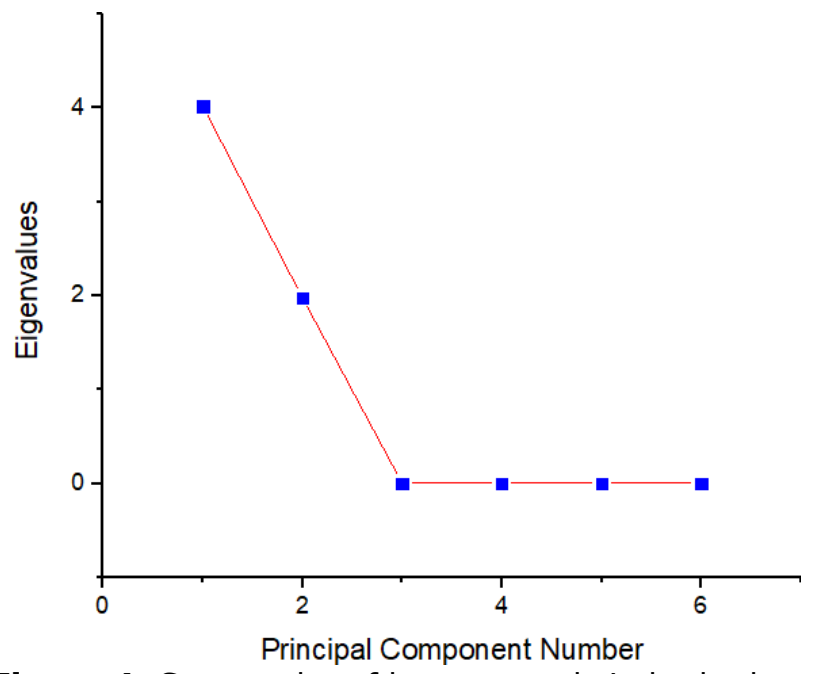

Figure 4: Screen plot of heavy metals in both plants Figure 5: Bi-plot of heavy metals in plants leachates. and leachate samples.
Figure 6 below. PC 1 is strongly correlated with these metals ( $\mathrm{Zn}, \mathrm{Mn}, \mathrm{Ni}, \mathrm{Cd}, \mathrm{Pb})$ in leachates and negatively correlated with $\mathrm{Cr}$ while PC 2 is strongly correlated with $\mathrm{Zn}, \mathrm{Cd}$, and $\mathrm{Cr}$, but negatively below. Table 6 below indicates the PC 1 and PC2 of heavy metals in plant samples. $P C 1$ is strongly correlated with $\mathrm{Zn}, \mathrm{Ni}, \mathrm{Cd}, \mathrm{Pb}$, and $\mathrm{Cr}$ but negatively correlated with $\mathrm{Mn}$. While PC 2 is strongly correlated with $\mathrm{Mn}, \mathrm{Pb}$, and $\mathrm{Cr}$ but negatively correlated with $\mathrm{Zn}, \mathrm{Ni}$, and $\mathrm{Cd}$. With the statistical data from the principal component analysis, it can be deduced that the heavy metals from this landfill are heavily polluted by anthropogenic sources $(17,34,37)$.

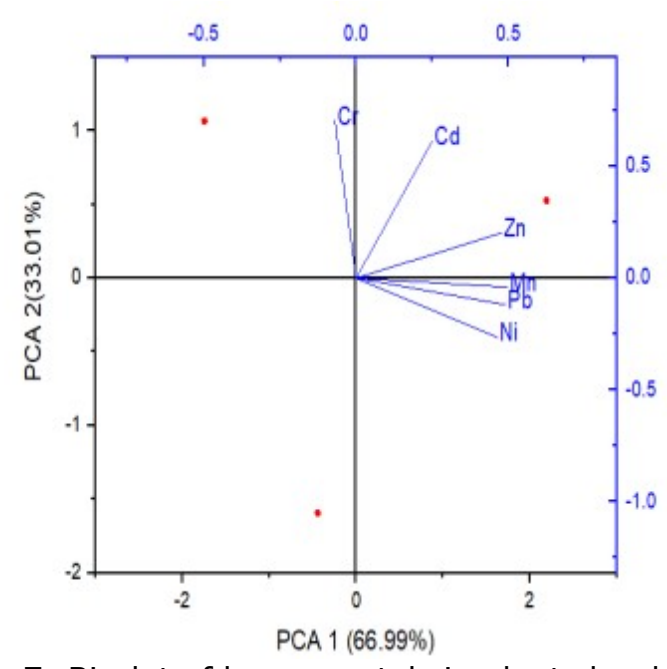
corrected with $\mathrm{Mn}, \mathrm{Ni}$, and $\mathrm{Pb}$ as shown from Table 5

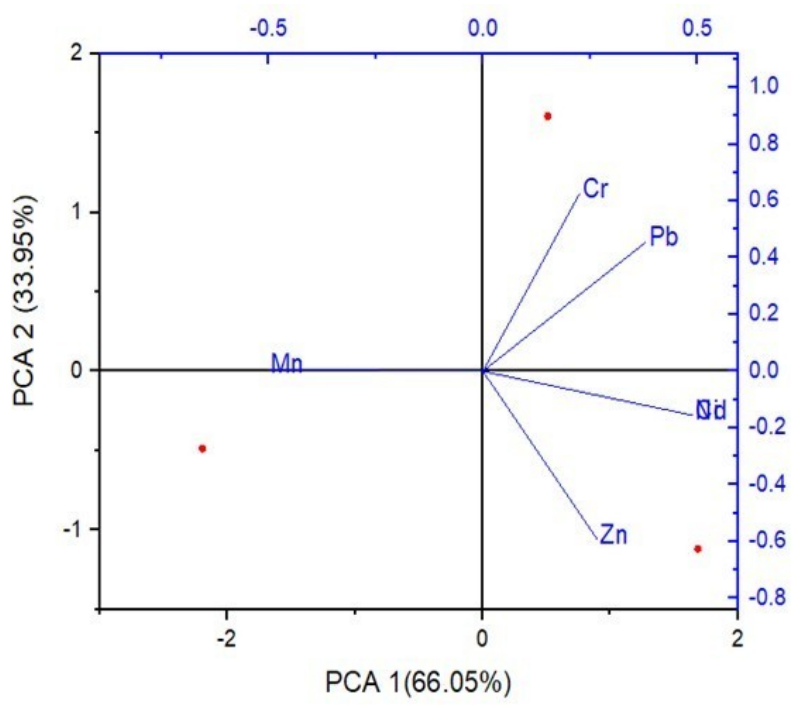

Figure 6: Bi-plot of heavy metals in leachates from Olusosun landfill. 
Table 5: Extracted eigenvalues of the heavy metals in leachate samples.

\begin{tabular}{ccc} 
& Coefficients of PC1 & Coefficients of PC2 \\
\hline $\mathrm{Zn}$ & 0.4781 & 0.2026 \\
$\mathrm{Mn}$ & 0.4980 & -0.0397 \\
$\mathrm{Ni}$ & 0.4627 & -0.2653 \\
$\mathrm{Cd}$ & 0.2504 & 0.6145 \\
$\mathrm{~Pb}$ & 0.4916 & -0.1198 \\
$\mathrm{Cr}$ & -0.0701 & 0.7035 \\
\hline
\end{tabular}

Table 6: Extracted eigenvalues of the heavy metals in leachate samples.

\begin{tabular}{ccc}
\hline & Coefficients of PC1 & Coefficients of PC2 \\
\hline $\mathrm{Zn}$ & 0.2675 & -0.5931 \\
$\mathrm{Mn}$ & $-0,5023$ & 0.0091 \\
$\mathrm{Ni}$ & 0.4899 & -0.1551 \\
$\mathrm{Cd}$ & 0.4899 & -0.1551 \\
$\mathrm{~Pb}$ & 0.3813 & 0.4562 \\
$\mathrm{Cr}$ & 0.2256 & 0.6260 \\
\hline
\end{tabular}

\section{Concentrations of PAHs in leachates and plant leaves}

Table 7 shows the concentration of PAHs in leachate samples. Sixteen PAHs are recognized by the United States Environmental Protection Agency (EPA) and are classified as low molecular weight (LMW, petrogenic), medium molecular weight (MMW), and high molecular weight (HMW, pyrogenic). The following PAHs were detected in leachate and plant samples: HMW - chrysene, benzo(b)fluoranthene, and benzo(a)anthracene; MMW - pyrene and fluoranthene and LMW - phenanthrene. The concentration range (mg/L) for the detected PAHs in landfill leachates were: LMW: 0.17 - 0.22; MMW: 0.15 - 0.24 and HMW: $0.10-0.19$ mg/L, respectively. The presence of LMW PAHs in the environment usually results from the emission of oil spills, noncombustible matter, and agricultural sources, while MMW and HMW PAHs are emitted mainly from sources like incomplete combustion/pyrolysis of organic matter and solid wastes, and incorporated into landfill leachate by rainwater (3). Municipal and waste discharge from industrial sites are part of the factors causing a high concentration of PAHs in leachates (38). The result of PAHs concentration in plant leaf samples is shown in Table 8. The concentration of PAHs in plant samples ranged between 0.09 - 0.31 $\mathrm{mg} / \mathrm{kg}$. Since P1 is far away and P2 and P3 are close, no PAHs were detected in P1, and some levels of PAH were found in P2 and P3.

Table 7: Concentration of polycyclic aromatic hydrocarbons found in leachates.

\begin{tabular}{llllll}
\hline & $\begin{array}{l}\text { Concentration } \\
\text { (mg/L/) }\end{array}$ & \multicolumn{2}{l}{ Concentration (mg/L/) } & \\
PAHs & L1 & L2 & PAHs & L1 & L2 \\
\hline Anthracene & BDL & BDL & Pyrene & 0.15 & 0.19 \\
Acenaphthene & BDL & BDL & Perylene & BDL & BDL \\
Phenanthrene & 0.22 & O.17 & Chrysene & 0.10 & 0.13 \\
Acenaphthylene & BDL & BDL & Benzo(b)fluoranthene & 0.19 & 0.15 \\
Naphthalene & BDL & BDL & Benzo(k)fluoranthene & BDL & BDL \\
Fluorene & BDL & BDL & Benzo(a)an thracene & 0.14 & 0.16 \\
Fluoranthene & 0.21 & 0.24 & Indeno(1,2,3-cd)pyrene & BDL & BDL \\
\hline
\end{tabular}


Table 8: Concentration of PAHs in plant leaves.

\begin{tabular}{llll}
\hline & \multicolumn{3}{l}{ Concentration $(\mathrm{mg} / \mathrm{kg})$} \\
\hline PAHs & $\mathrm{P} 1$ & $\mathrm{P} 2$ & $\mathrm{P} 3$ \\
Naphthalene & $\mathrm{BDL}$ & $\mathrm{BDL}$ & $\mathrm{BDL}$ \\
Acenaphthylene & $\mathrm{BDL}$ & $\mathrm{BDL}$ & $\mathrm{BDL}$ \\
Acenaphthene & $\mathrm{BDL}$ & $\mathrm{BDL}$ & $\mathrm{BDL}$ \\
Fluorene & $\mathrm{BDL}$ & $\mathrm{BDL}$ & $\mathrm{BDL}$ \\
Phenanthrene & $\mathrm{BDL}$ & 0.31 & 0.19 \\
Anthracene & $\mathrm{BDL}$ & $\mathrm{BDL}$ & $\mathrm{BDL}$ \\
Fluoranthene & $\mathrm{BDL}$ & 0.16 & 0.14 \\
Pyrene & $\mathrm{BDL}$ & 0.24 & 0.11 \\
Benz(a)anthracene & $\mathrm{BDL}$ & 0.17 & 0.14 \\
Chrysene & $\mathrm{BDL}$ & 0.09 & 0.13 \\
Benzo(b)fluoranthene & $\mathrm{BDL}$ & 0.11 & 0.17 \\
Benzo(k)fluoranthene & $\mathrm{BDL}$ & $\mathrm{BDL}$ & $\mathrm{BDL}$ \\
Benzo(a)pyrene & $\mathrm{BDL}$ & $\mathrm{BDL}$ & $\mathrm{BDL}$ \\
Indeno(1,2,3-cd)pyrene & $\mathrm{BDL}$ & $\mathrm{BDL}$ & $\mathrm{BDL}$ \\
Dibenzo(a,h)anthracene & $\mathrm{BDL}$ & $\mathrm{BDL}$ & $\mathrm{BDL}$ \\
Benzo (g,h,i) perylene & $\mathrm{BDL}$ & $\mathrm{BDL}$ & $\mathrm{BDL}$ \\
\hline & $\mathrm{E}=0.0000 \Sigma=1.08$ & $\Sigma=0.88$
\end{tabular}

Table 9: Pearson correlation matrices of PAHs from leachate samples in the Olusosun landfill.

\begin{tabular}{lllllll}
\hline & Phe & Flu & Pyr & Chy & Benzo(b)F & Benzo(a)A \\
\hline & 1 & & & & & \\
Phe & 0.0576 & 1 & & & & \\
Flu & 0.8572 & 0.5636 & 1 & & & \\
Pyr & 0.8934 & 0.5000 & 0.9972 & 1 & & \\
Chy & 0.4018 & -0.8910 & -0.1273 & -0.0524 & 1 & \\
Benzo(b)F & -0.7825 & 0.5766 & -0.3500 & -0.4193 & -0.8846 & 1 \\
Benzo(a)A & 0.7924 & 0.6547 & 0.9934 & 0.9820 & -0.2402 & -0.2402 \\
\hline
\end{tabular}

Phe- Phenanthrane; Flu- Fluoranthene; Pyr- Pyrene; Chy- Chrysene; Benzo (b)- Benzo(b)fluoranthene; Benzo(a)A- Benzo(a)anthracene

Table 10: Pearson correlation matric of PAHs from plant samples in the Olusosun landfill.

\begin{tabular}{lllllll}
\hline & Phe & Flu & Pyr & Chy & Benzo(b)F & Benzo(a)A \\
\hline Phe & 1 & & & & & \\
Flu & 0.9477 & 1 & & & & \\
Pyr & 0.7341 & 0.4790 & 1 & & & \\
Chy & 0.9995 & 0.9368 & 0.7559 & 1 & & \\
Benzo(b)F & -0.3192 & $3.61 \mathrm{E}-17$ & -0.8778 & -0.3499 & 1 & \\
Benzo(a)A & -0.4039 & -0.0908 & -0.9177 & -0.4336 & 0.9959 & 1 \\
\hline
\end{tabular}

The Pearson correlation of PAHs in leachates in shown from Table 9 above. A positive correlation exists between some PAHs found in leachates with significant difference $>0.05$ which includes: Pyr/Phe, Flu/Phe, Pyr/Flu, Chy/Phe, Benzo(a)A/flu, Benzo(b)F/ Flu, Benzo(a)A /Phe and a negative correlation exists between Benzo(b)F /Phe, Chy/Flu, Benzo(b)F/Phe, Benzo(b)/ Pyr, Benzo(a)A/ Benzo(b)F and Chy/Pyr. Also, a positive correlation exists between Phe/Flu, Chy/Phe, Flu/Pyr, Benzo(b)F/ Benzo(a)A Pyr/Phe, Chy/Flu, Phe/Chy, Pyr/Chy, and negative correlation occurred between Phe/ Benzo(b)F, Phe/ Benzo(a)A, Chy/ Benzo(b)F, Benzo(a)A, Chy, Benzo(a)A/Pyr with a significant difference $>0.05$ in plants as shown in Table 10 above. It indicates that the source of contamination in this study is a result of different anthropogenic activities that take place in the landfill. 
Table 11: Extracted eigenvalues of the PAH in leachate samples.

\begin{tabular}{lll}
\hline & $\begin{array}{l}\text { Coefficients } \\
\text { of PC1 }\end{array}$ & $\begin{array}{l}\text { Coefficients } \\
\text { of PC2 }\end{array}$ \\
\hline Phenanthrene & 0.4812 & -0.1872 \\
Fluoranthene & 0.4716 & 0.2317 \\
Pyrene & 0.4825 & 0.1806 \\
Chrysene & 0.1013 & -0.6957 \\
Benzo(b)fluoranthene & -0.3174 & 0.5481 \\
Benzo(a)anthracene & 0.4498 & 0.3072 \\
\hline
\end{tabular}

Table 12: Extracted eigenvalues of the $\mathrm{PAH}$ in plant samples removed from the plants.

\begin{tabular}{lll}
\hline & $\begin{array}{l}\text { Coefficients } \\
\text { of PC1 }\end{array}$ & $\begin{array}{l}\text { Coefficients } \\
\text { of PC2 }\end{array}$ \\
\hline Phenanthrene & 0.4415 & 0.3221 \\
Fluoranthene & 0.3495 & 0.5156 \\
Pyrene & 0.4706 & -0.2109 \\
Benz(a)anthracene & 0.4483 & 0.3004 \\
Chrysene & -0.3454 & 0.5217 \\
Benzo(b)fluoranthene & -0.3757 & 0.4727 \\
\hline
\end{tabular}

The variance of PAHs in leachate and plant samples analyzed are $66.98 \%, 33.02 \%$; 69.02\%, 30.98\% for PC1 and PC2, respectively, as shown from Figures 7 and 8 below. The scree plot of PAHs in plants and leachates proved the components that are retrained, as shown in Figure 8 below. Components 1 (4.34) and $2(1.77)$ are retained because it is greater than unity $(35,36)$ while other components (3,4 and 5) are not retained. There is a strong positive correlation between the PAHs in PC1 for leachate samples includes; Phenanthrene, Fluoranthene, Pyrene, Chrysene, and Benzo(a)anthracene but negative correlation occurred at Benzo(b)fluoranthene. While the positive correlation was seen between the PAHs in PC2 includes; Fluoranthene, pyrene,
Benzo(b)fluoranthene and Benzo(a)anthracene but negative correlation exists in Phenanthrene and Chrysene as shown from Table 11 above. For plant samples, a positive correlation exists between Phenanthrene, Fluoranthene, pyrene, Benzo(a)anthracene, and a negative correlation exists between Chrysene and Benzo(b)fluoranthene for PC1. A positive correlation exists between these PAHs (Phenanthrene, Chrysene, Fluoranthene, Benzo(b)fluoranthene and Benzo(a)anthracene) and pyrene only had a negative correlation in PC2 as shown from Table 12 above. However, the statistical data from this study confirmed that the source of PAHs was through resistance to environmental degradation, surface run-off (17), and type of waste deposited on the landfill.

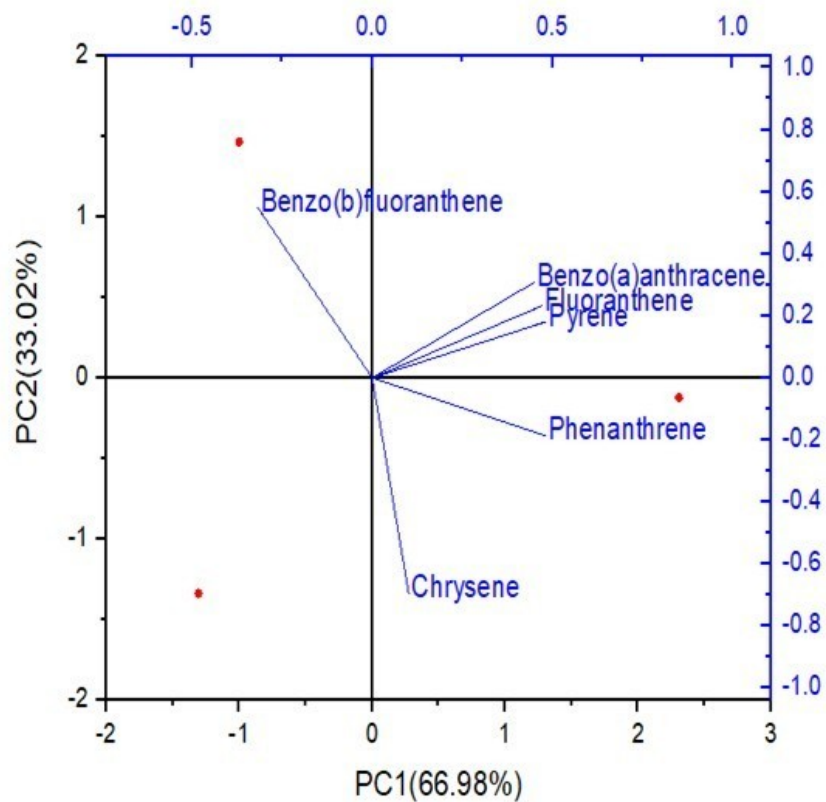

Figure 7: Biplot of the $\mathrm{PAH}$ in leachate samples.

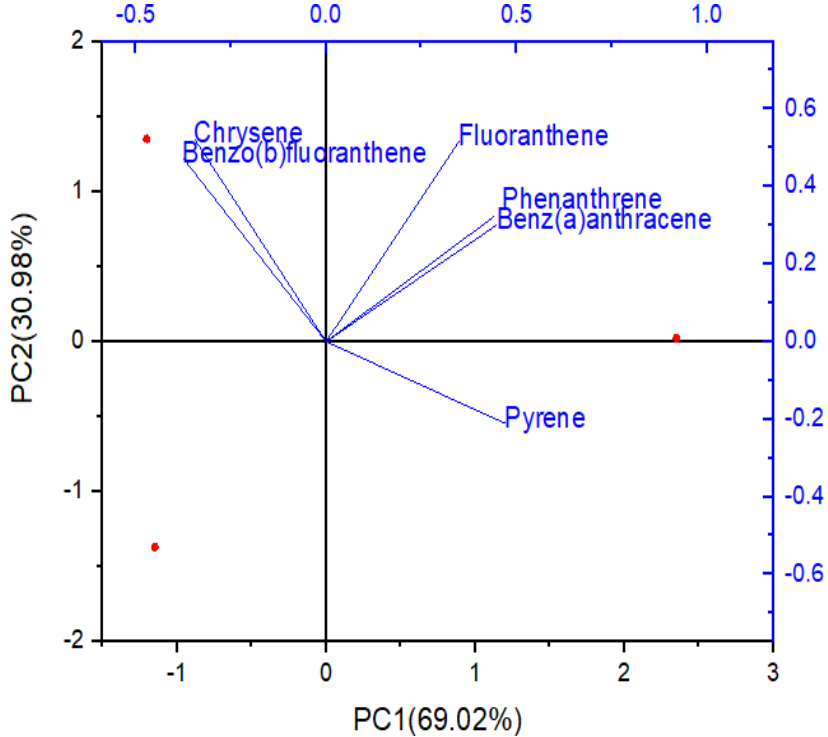

Figure 8: Bi-plot of $\mathrm{PAH}$ in plant samples. 


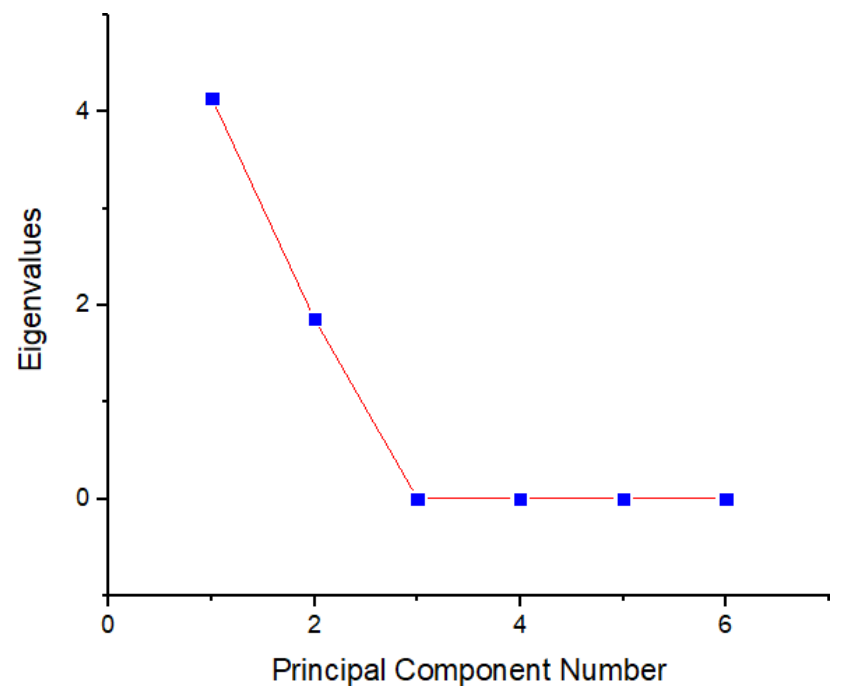

Figure 9: Screen plot of PAHs in plants.

\section{CONCLUSION}

Six (6) PAHs each were detected in both the plant and leachate samples analyzed, which includes the following: Chrysene, Benzo (b)fluoranthene, Benzo (a) anthracene, Phenanthrene, Pyrene, and Fluoranthene. Heavy metals such as Zinc ( $\mathrm{Zn})$, Lead $\mathrm{Pb}$, Chromium (Cr), Manganese $(\mathrm{Mn})$, Cadmium (Cd), and Nickel (Ni) were also detected. The majority of the physicochemical parameters analyzed were found to exceed their permissible limits set by WHO and NESREA. The source of pollution in this study is the same, and it is confirmed by the statistical analysis used. With the results obtained from this study, it could be deduced that the landfill is heavily polluted, and adequate management needs to be put in place by various agencies.

\section{ACKNOWLEDGEMENT}

The authors are grateful to the Department of Plant Biology, University of Ilorin, Ilorin, for the identification of the plant samples and Department of Industrial Chemistry, University of Ilorin, Ilorin, for providing the laboratory facilities used for this research.

\section{CONFLICT OF INTEREST}

All the authors declare no conflict of interest regarding this manuscript

\section{REFERENCES}

1. Adeolu OA, Gbenga AA, Adebayo, AO. Municipal landfill leachate characterization and its induction of glycogen vacuolation in the liver of Clariasgariepinus: International Journal of Environmental Protection 2009; (2):20-4.

2. Moqsud MA, Rahman MH. Biochemical quality of compost from kitchen garbage in

Bangladesh. Environmental Informalities Archive 2004; (2): 635- 40.
3. Zakaria MP, Geik KH, Lee WY, Hayet R. Landfill leachate as a source of polycyclic aromatic hydrocarbons (PAHs) to Malaysian waters. Coastal Marine Science 2005; 29(2): $116-23$.

4. Mull EJ, Approaches toward sustainable urban solid waste management in Nigeria. Iranian Journal of Environmental Health Sciences and Engineering 2005; (6): $173-80$.

5. Bakare AA, Alimba CG, Alabi, OA. Genotoxicity and mutagenicity of solid waste leachates: A review. African Journal of Biotechnology 2013; 12(27): 4206 - 20. doi: 10.5897/ajb2013.12014.

6. Al-Khaldi S. Assessment of groundwater contamination vulnerability in the vicinity of Abqaiq landfill- A GIS Approach", King Fahd University of Petroleum and Minerals, Saudi Arabia, 2006.

7. Rafizul IM, Alamgir M, Kraft E, Haedrich G. Biotreatment of leachate generated from municipal solid waste in sanitary landfill lysimeter. 2nd International conference on solid waste management in developing Asian countries, KUEST, Bangladesh, 2011, pp. $191-3$.

8. Christensen $T H$, Kjeldsen $P$, Bjerg $P L$, Jensen $D L$, Christensen, JB, Baun A, Albrechtsen HJ, Heron G. Biogeochemistry of landfill leachate plumes. Applied Geochemistry 2000; (6): 659 - 718. doi: 10.1016/s08832927(00)00082-2

9. Pivato A, Gaspari L. Acute toxicity test of leachates from traditional and sustainable landfills using luminescent bacteria. Waste Management 2005; (26): 1148 - 55. doi:10.1016/j.wasman.2005.10.008

10. Ogundiran OO, Afolabi TA, Assessment of the physiochemical parameters and heavy metal toxicity of leachates from municipal solid waste open dumpsite. International Journal of Environmental Science and Technology 2008; 5(2): $243 \quad$ - 50. doi:10.1007/bf03326018

11. Hussein IA, Mona SMM. A review on polycyclic aromatic hydrocarbons:Source, environmental impact, 
effect on human health and remediation 2016(1):107 - 23 . doi: $10.1016 /$ j.ejpe.2015.03.011

12. Salami L, Fadayini O, Patinvoh RJ, Koleoba, $O$. Evaluation of leachate contamination potential of Lagos dumpsites using leachate pollution index. British Journal of Applied Sciences and Technology 2015; 5(1): 48 - 59. doi: 10.9734/bjast/2015/11707.

13. Longe EO, Enekwechi LO. Investigation on potential groundwater impacts and influence of local hydrogeology on natural attenuation of leachate at a municipal landfill. International Journal of Environmental Science Technology 2007; 4(1):133 - 40 .

14. Odunaiya CO. Repositioning solid waste management practices in cosmopolitan Lagos. Lagos State Polytechnic Inaugural Lecture Series No. 6, 2002, pp. 66

15. Oyetola OT, Babatunde AI. Effect of municipal solid waste in Olusosun dumpsite, Lagos state, Nigeria, International Journal of Pure Applied Science 2008; 2(1): $17-21$.

16. Olujimi OO, Ajayi OL, Opotu OU. Toxicity Assessment of Olusosun and Igando leachates using the African catfish (Clarias gariepinus) as bioindicator species, part 1 . Ife Journal of science 2015, 18(3): 693 - 701.

17. Oketola AA, Akpotu SO. Assessment of solid waste and dumpsite leachate and topsoil. Chemistry and Ecology 2015; $31(2): \quad 134 \quad$ - 46. doi.org/10.1080/02757540.2014.907280 .

18. Lagos Waste Disposal Board. Organization development and waste management system project, Lagos Waste Disposal Board. Assessment report, 2006, 1: $1-5$.

19. Lagos Waste Management Authority, 2011. Olusosun Landfill site. Retrieved from: http://www.lawma.gov.ng/lawma_landfill.html

20. APHA (American Public Health Association) Standard methods for the examination of water and wastewater 23rd edition 2017, Washington, USA.

21. Kanmani S, Gandhimathi R. Assessment of heavy metal contamination in soil due to leachate migration from an open dumping site. Applied Water Science 2013; 3: 193 - 205. doi:10.1007/s13201-012-0072-z .

22. Farshid $\mathrm{K}$, Amir HS, Rokhsare $M$. Determination of polycyclic aromatic hydrocarbons (PAHs) in water and sediments of the Kor River. Iranian Middle - East Journal of Science Resources 2011; 10(1):1 - 7 .

23. Okoli CG, Ogbuagu DH, Gilbert CL, Madu S, Njoku RF. Proximal input of polynuclear aromatic hydrocarbons (PAHs) in groundwater sources of Okrika Mainland, Nigeria. Journal of Environment Protection 2011; (2): 848 - 54. doi: $10.4236 /$ jep.2011.26096.

24. Ujowundu CO, Ihekweazu KL, Alisi CS, Ujowundu FN, Igwe CU. Procarcinogens: Polycyclic aromatic hydrocarbons and heavy metal content in some locally processed foods in South Eastern Nigeria. British Journal of Applied Science Technology 2014; 4(1): 249 - 60. doi: $10.9734 /$ bjast/2014/4668.
25. Chian E, DeWalle F. Sanitary landfill leachates and their treatment. Journal of Environmental Engineering Division 1976; ASCE (102): 411 - 31.

26. Chu L, Cheung K, Wong M. Variations in the chemical properties of landfill leachates. Environmental Management 1994; (18): $105 \quad$ - 17. doi: $10.1007 /$ bf02393753 .

27. Tesi GO, Iniaghe PO, Iniaghe OP, Rotu AR. Assessment of the quality of water from boreholes and hand-dug wells of peri-urban towns in southern Nigeria. Journal of Environmental Management Safety 2013; 4(3): $39-46$.

28. Adeyemi-Ale OA, Anifowoshe AT, Abdulkareem SI. Ecotoxicological Assessment of leachate from Amilegbe Dumpsite, Ilorin, Nigeria Using Clarias gariepinus (Burchell 1822) AND Allium cepa. Agrosearch (2018) 18 (2): 59 71. doi:10.4314/agrosh.v18i2.5

29. World Health Organization (WHO) Water for pharmaceutical use in quality assurance of pharmaceuticals. A compendium of guidelines and related materials, 2nd Updated Edition, World Health Organization, Geneva, 2007, pp. $170-87$.

30. National Environmental Standards and Regulations Enforcement Agency (NESREA) (Surface and Groundwater Quality Control) Regulations- Effluent discharges, irrigation and reuse standards, 2011.

31. Radojevic M, Bashkin V. Practical environmental analysis, Cambridge: The Royal Society Chemistry, London, 1999.

32. Schindler DW, Hecky RE, Findlay $D L$, Stainton $M P$, Parker BR, Paterson M, Beaty KG, Lyng M, Kasian SEM (2008) Eutrophication of lakes

cannot be controlled by reducing nitrogen input: results of a 37-year whole ecosystem experiment. Proceedings of National Academy of Science, USA, 2008; (105): 11254 8. doi:

10.1073/pnas.0805108105 .

33. World Health Organization (WHO) Permissible limits of heavy metals in soil and plants (Geneva: World Health Organization), Switzerland, 1996.

34. Bhardwaj R, Gupta A, Garg JK (2017) Evaluation of heavy metal contamination using environmetrics and indexing approach for River Yamuna, Delhi stretch, India. Water Science2017; (31): 52 - 66. doi: 10.1016/j.wsj.2017.02.002 .

35. Nair IV, Singh K, Arumugam M, Gangadhar K, Clarson, D. Trace metal quality of Meenachil River at Kottayam, Kerala (India) by principal component analysis. World Applied Science 2010; 9(10): $1100-7$.

36. Okoro HK, Ogunsemoyin OT, Mohammed AA. Assessment of Heavy Metal Pollution Roadside Dusts from Selected Locations in Ilorin, Nigeria Using AAS Techniques. Adamawa State University Journal of Science Research $2016 ; 4(1): 1-12$.

37. Jena VK, Sinha D. Ground water quality assessment by multivariate factor analysis. Research Journal of Chemistry and Environment 2017; 21(8): $21-5$. 
38. Baran S, Oleszczuk, P, Lesiuk A, Baranowska E. Trace metals and polycyclic aromatic hydrocarbons in surface sediment samples from the Narew River (Poland). Polish Journal of Environmental studies 2002; (11): 299 - 305. 
